\title{
Nietzsche: madness as literature
}

\author{
Eva M. Cybulska
}

The life of Friedrich Nietzsche (1844-1900), one of the most profund thinkers of the last 150 years, culminated in mental illness. A determined opponent of Hegel and Kant, he was also a great inspiration to figures as diverse as Wittgenstein, Heidegger, Jaspers and Derrida. Mann, Hesse, Camus and Kundera wrote books with Nietzsche in mind, while Strauss and Scriabin composed music in Nietzschean spirit. Being one of the most influential writers, he was also one of the most controversial. Ironically, his ideas were readily appropriated by the Nazis (thanks to his Machiavellian sister!), so that the "philosopher of truth' has also become known as a philosopher of evil. Such is the fate of those who have the courage (and the intellect) to hit at the very centre of existential paradoxes and absurdities, those who in his own words "philosophise with a hammer". Nietzsche's penetrating psychological insights have assured him an unassailable place as the precursor to psychoanalysis.

Yet, primarily, Nietzsche was not a philosopher but a philologist. He became a professor of classical literature at Basel University at the age of 24, only to resign ten years later and spend the next decade travelling round Europe and writing. His career came to an abrupt end when at the age of 44 he developed a mental illness and was admitted to Jena asylum with a diagnosis of paralysis progressiva. On admission he claimed to have infected himself twice with syphilis. The medical profession was only too eager to swallow this most successful of 'fish-hooks'. A metaphor instantly solidified. Despite no evidence other than Nietzsche's disturbed mental state and his own confession, the diagnosis has stuck for more than a hundred years. To use his own expression, "the untruth became a condition of life". Why would Nietzsche, who most probably died a virgin, have taken upon himself such a 'sin'?

Nietzsche's drift towards madness cannot be separated from his life, and his life cannot be separated from his philosophy. Being the eldest son of a Lutheran pastor no doubt influenced his attitude to religion. The idyllic and soothing images that frequently returned to him were those of sitting on his father's lap and listening to his musical improvisations. The tragedy struck when the pastor died unexpectedly at the age of 36 , leaving Friz, aged $4 \frac{1}{2}$, to be the eldest man in the household. The vague, if enigmatic, post mortem diagnosis of 'softening of the brain' left Nietzsche with a lifelong fear of having inherited his father's illness. In a letter to Carl von Gersdorff in January 1876 he wrote: "After even more frequent attacks, it came to a literal collapse. I could no longer doubt that I am suffering from a serious brain illness, and that my eyes and stomach have only suffered as a result of this central process. My father died at 36 from a brain infection and it is possible that it will go even faster with me." There were two major infectious diseases in the 19th century that resulted in great biological devastation and even greater psychological fear. These were tuberculosis and syphilis. What matters, however, in Nietzsche's case is not so much the reality but the fear. In the play Ghosts, Henrik Ibsen (1964) describes the son's fear of having inherited syphilis from his deceased father.

Osvald: The disease that I have inherited (he points to his forehead and goes on very softly) - is seated here. Mrs Alvig: Osvald! No! No!

Osvald: Don't scream, I couldn't bear it. Yes, it sits here and waits. And it may break out any day - any minute.

Mrs Alvig: Then this is the fear.

Osvald: Yes, you see, it is so unspeakably loathsome.... To become like a helpless child again, to have to be fed ... . I daren't think I might linger on for years - untll I am old and grey .... Because the doctor told me it might not be fatal at once. He called it a kind of softening of the brain, or something of the sort.

Osvald kills himself in anticipation.

Father and sons need one another. Kierkegard (1945) wrote in Stages on Life's Way: "There was once a father and son. The son is like a mirror in which father beholds himself and for the son the father too is like a mirror, in which he beholds himself in the time to come". Nietzsche said in Thus Spoke Zarathustra (1954): "What was silent in the father speaks in the son; and I often found the son the unvelled secret of the father". In his philosophy Nietzsche often stressed that truth is created, not discovered. Could it be that by appropriating his father's real or perceived sin, he made a last and desperate attempt to recreate the past? The guilt for winning an Oedipal duel was thus settled . . . 
The clouds of psychosis were gathering for several months before his final collapse. At that time Nietzsche was staying in a small pensione in Turin. He wrote to his sister that people were treating him preferentially and everybody glanced at him as if he were a prince. He tended to confuse mental events with external ones. He wrote grandiose, disinhibited letters to various heads of state, Cossima Wagner, Burkhardt and Strindberg, signing himself Crucifled, Dionysus and Caesar.

On the morning of the 3 January 1889 he left his lodgings and walked to Piazza d'Alberto. There he saw a cab driver beating his horse. Nietzsche burst into tears, flung his arms around the animal's neck and collapsed. This appears to be a sheer re-enactment of a scene from Crime and Punishment by Dostoveyvsky (1991) (a book he read two years previously) and described below.

On the day before the murder Raskolnikov had a horrific dream. His family, like Nietzsche's, consisted of a mother, sister, a deceased father and a baby brother. In his dream Raskolnikov walked with his father along the road that led to the cemetry, holding his hand. They were passing the tavern in front of which stood one of these enormous wagons, used for transporting wine and various goods. A small pitiful horse was hitched on to it. Suddenly a great row erupted in the tavern and several muzhiks came out completely drunk, yelling, singing and playing the guitar. Mikolka and six others jumped on the wagon, and yelling at the horse tried to make him gallop by whipping him from all sides. The animal collapsed but this did not prevent the peasants from continuing to beat him. "Rodion has come to the little horse. He sees it get whipped on the eyes, yes on the eyes. His heart swells up, tears are streaming down his face ... The mare is dead. But the poor little boy is beside himself. Screaming he forces a path for himself through the crowd surrounding the roan mare. He takes the bloody head of the cadaver into his hands and kisses it, kisses it on the eyes, on the lips ... Then in a fit of rage he clenches his little fists and throws himself upon Mikolka. At this moment his father finds him and leads him away from the crowd. 'Let's go' he said 'let's go'. 'Daddy! Why did they ... kill ... the poor horse?' The child sobs but he cannot catch his breath, and all that comes from his tight throat are rasping sounds ... He wants to breathe to scream and he wakes up."

Life as literature? Madness as literature? Throwing his arms around the neck of the suffering horse was for Nietzsche a synthesis and culmination of so many of his own repressed thoughts and feelings. Dreams, experiences and ideas merged into a symbol. According to Freud horses can be associated with fathers, as in the famous Schubert song 'Erlkönig'. A repressed longing for an intimate and protective father may well have been what the German philosopher shared with his Russian counterpart. Nietzsche loved theatre. Deep in his heart he remained a man of literature, faithful to Sophoclean tragedy. He called himself a 'philosopher of masks' and chose the god Dionysus as his patron. In his philosophy he looked at people as if they were literary characters and at life as if it were a work of literature. What mattered for a character was not to be 'good' or 'bad' from a moral point of view, but to have a style, to create oneself continually, and thus to stand beyond good and evil. This is, in a nutshell, the essence of Übermensch. Nietzsche (1974) often urged that we should fashion our lives in the way artists fashion their work, so that we become "the poets of our life". And this is precisely what he did.

\section{References}

Dostoyevsky, F. (1991) Crime and Punishment, pp. $192-$ 194. London: Penguin Books.

IBSEN, H. (1964) Ghosts, p. 98. London: Penguin Books

KIERKEGAARD, S. (1945) Stages on Life's Way (trans. W. Lowrie). London: Humphrey Milford, Oxford University Press.

NieTzSCHE, F. (1954) Thus Spoke Zarathustra. In Portable Nietzsche (trans. W. Kaufmann). New York: Viking Penguin.

- (1974) The Gay Science (trans. W. Kaufmann). New York: Random House.

Eva M. Cybulska, Consultant Psychiatrist, Stone House, Thameslink Healthcare Services, NHS Trust, Cotton Lane, Dartford, Kent DA2 6AU 